\title{
PENTINGNYA PERAN LOGO DALAM MEMBANGUN BRAND
}

\author{
Angela Oscario \\ Jurusan Desain Komunikasi Visual, School of Design, BINUS University \\ Jln. K. H. Syahdan No. 9, Palmerah, Jakarta Barat 11480 \\ oscario_box@yahoo.com
}

\begin{abstract}
Brand is an intangible asset of an entity. It's a summary of experiences of an entity. Well-developed brand is a very high value asset, even higher than all of the physical assets owned by the entity. Because brand is created on people's mind, brand can build customer's loyalty. Brand can be built in many ways. One of the most important way is designing visual indentity, such as logo. Logo is a graphical element in the form of ideogram, symbol, emblem, icon, sign that is collectively form a trademark or commercial brand. Logo is the entrance that reflects a brand. Because of that, a logo must reflect the soul of the entity. Considering how important a logo for a brand, a logo should be designed seriously. Ironically, there're so many fast, and cheap logo design services that create an instant logo. Why is it happened? It's because the brand owners have a lack of awareness of the important of a brand and a logo. It's also because there are a lot of designers who have no respect on their profession. These kind of designers offer cheap services for an easy money with a little work. This situation can be bad for both of the brand owner and the designer. The price of logo design will be cheaper and cheaper, and the brand will not be developed well. That's why it's important to raise the awareness of the importance of a branding and a well designed logo which represent the soul of the entity.
\end{abstract}

Keywords: brand, logo, the soul of an entity, asset

\begin{abstract}
ABSTRAK
Brand adalah aset tak berwujud yang berupa rangkuman pengalaman terhadap sebuah entitas. Nilai aset sebuah brand yang terbangun baik sangatlah tinggi, bahkan bisa melebihi semua aset fisik entitas yang bersangkutan. Karena diciptakan dalam pikiran, brand dapat membangun loyalitas pelanggan. Salah satu kegiatan membangun brand yang sangat penting adalah mendesain identitas visual, seperti logo. Logo adalah elemen grafis berbentuk ideogram, simbol, emblem, ikon, tanda yang digunakan sebagai lambang sebuah brand. Logo adalah pintu masuk yang mencerminkan sebuah brand. Oleh sebab itu, logo harus dapat menampilkan pribadi dan jiwa entitas yang diwakilinya. Mengingat betapa pentingnya logo bagi sebuah brand, sudah sepantasnya proses pendesainan logo dirancang dengan serius. Ironisnya, layanan-layanan desain logo yang cepat, murah dan menghasilkan logo yang instan malah marak di masyarakat. Kurangnya kesadaran akan pentingnya brand dan logo di kalangan pemilik brand menjadi salah satu penyebabnya. Di samping itu penghargaan akan profesi desainer di kalangan desainer sendiri juga kurang terbangun. Para desainer berlomba-lomba menawarkan jasa murah demi mendapatkan uang cepat dan kerja ringan. Hal ini dapat menjadi lingkaran setan yang berakibat buruk bagi kalangan desainer maupun pemilik brand. Harga desain logo akan semakin turun, dan brand sendiri tidak akan terbangun dengan baik. Oleh sebab itu penting untuk membangkitkan kesadaran akan pentingnya membangun brand dan merancang logo yang dapat mencerminkan jiwa entitas yang bersangkutan.
\end{abstract}

Kata kunci: brand, logo, pribadi entitas, aset 


\section{PENDAHULUAN}

Brand adalah aset yang paling berharga bagi sebuah bisnis. Bahkan nilai sebuah brand melebihi gabungan seluruh properti, dan peralatan yang dimiliki sebuah bisnis. Sebenarnya apa yang disebut dengan brand? Brand adalah aset tak berwujud yang berupa rangkuman pengalaman terhadap sebuah entitas. Walter Landor, pendiri Landor Associates, lebih spesifik mengatakan bahwa brand diciptakan dalam pikiran. Brand yang sukses dapat membangun sebuah identitas atau kepribadian yang dapat menjalin hubungan antara perusahaan dan pelanggan.

Lalu bagaimana sebuah brand dapat diciptakan? Branding - istilah kegiatan membangun brand - meliputi penciptaan identitas visual, komunikasi hingga pembentukan perilaku/budaya perusahaan. Penciptakan identitas visual merupakan salah satu cara membangun brand secara fisik yang sangat penting. Dan salah satu elemen utama dalam penciptaaan identitas visual adalah logo. Menurut Milton Glaser, logo adalah pintu masuk yang mencerminkan sebuah brand. Logo dapat mencerminkan wajah, dan kepribadian sebuah entitas.

Mengingat betapa berharganya brand bagi sebuah bisnis, dan mengingat pentingnya logo dalam membangun brand, sudah seharusnya logo didesain secara terencana matang. Namun sayangnya di Indonesia tampaknya kesadaran itu belum terbangun. Banyak logo yang dibuat dengan prinsip ”asal jadi”, dan bahkan menyadur visual dari stock imagery. Logo tidak direncanakan sedemikian rupa sehingga dapat mencerminkan jiwa perusahaan yang bersangkutan. Hal ini tercermin dari banyak kontes logo yang pada umumnya logo dibuat secara instan, banyak logo yang diperjualbelikan dengan harga di bawah standar, dan bahkan ada layanan yang menyediakan template pembuatan logo. Kenapa hal ini dapat terjadi? Dan bagaimana seharusnya sebuah logo dirancang? Melalui penulisan ini, diharapkan penghargaan terhadap pentingnya peranan logo dalam membangun branding, serta penghargaan terhadap branding itu sendiri dapat terbangun.

\section{METODE PENELITIAN}

Penelitian yang dilakukan untuk membuktikan pentingnya peranan logo dalam membangun branding ini dilakukan berdasarkan studi literatur dan studi lapangan. Pertama-tama, penulis melakukan pendekatan studi kaji, dengan menghadiri workshop, melihat pengalaman dan pengamatan pribadi penulis di lingkungan kerja. Selain itu, penulis melakukan studi literatur, dengan mencari berbagai sumber terkait pentingnya logo dalam branding melalui media cetak, maupun elektronik. Sumber informasi diseleksi, dievaluasi, dan dijadikan pendukung dalam penulisan ini.

\section{HASIL DAN PEMBAHASAN}

Dalam Wheeler (2009) disebutkan bahwa makna brand bisa berubah sesuai konteksnya. Kadang brand dapat dimaknai sebagai kata benda, kadang sebagai kata kerja. Kadang dapat diasosiasikan dengan nama entitas, pengalaman, dan harapan konsumen. Sementara itu, Rustan (2009) secara ringkas mendefinisikan brand sebagai rangkuman pengalaman, dan asosiasi terhadap sebuah entitas.

Kenapa penting bagi sebuah bisnis untuk membangun brand? Terkadang orang tak menyadari bahwa brand juga termasuk aset bisnis, walau tak berwujud. Hal yang lebih tidak disadari lagi bahwa brand adalah aset yang paling berharga dalam sebuah bisnis. Kenapa brand bisa disebut sebagai aset 
yang paling berharga? Sebagai contoh ilustrasi: dari hari ke hari pabrik, peralatan, serta perlengkapannya akan rusak, mengalami penurunan nilai, kuno/tertinggal secara teknologi, dan pada akhirnya harus diganti. Sebaliknya semakin lama brand, jika dibangun dengan penuh perencanaan, malah akan semakin kuat dan berharga. Pabrik akan selalu mengalami perubahan, namun nilai yang terkandung dalam brand akan terus hidup.

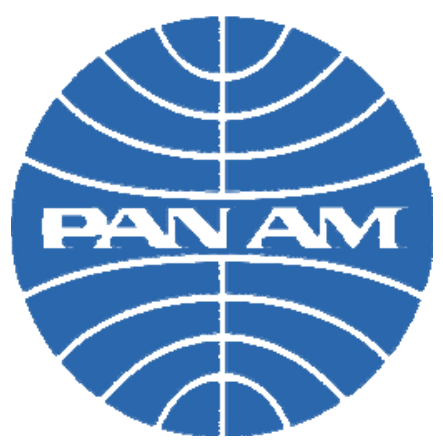

Gambar 1 Logo Pan Am

Sebagai contoh kasus: Pan Am, sebuah perusahaan penerbangan mengalami kebangkrutan pada tahun 1991. Seluruh aset fisik dilikuidasi. Aset yang tersisa hanyalah nama, dan logo Pan Am. Pada tahun 1993, seorang pebisnis, Charles E. Cobb ingin mendirikan sebuah perusahaan penerbangan. Dari pada membentuk perusahaan penerbangan dengan brand baru yang tidak dikenal orang, ia memutuskan untuk membeli brand Pan Am seharga 1,3 juta dolar. Dan pada tahun 1996, berdirilah sebuah perusahaan penerbangan baru yang bernama Pan American World Airways. Pada kasus ini Charles E. Cobb melakukan tindakan yang sangat cerdas. Mana yang akan memiliki kesempatan yang lebih besar untuk sukses, Cobb’s Airline atau Pan Am? Tentu brand yang sudah dikenal akan lebih populer dan lebih mudah mencapai kesuksesan dibanding brand baru yang tak dikenal sama sekali. Berdasarkan contoh kasus di atas, tergambar dengan jelas betapa berharganya dan bernilainya sebuah brand.

Dalam membangun sebuah brand, banyak hal yang harus direncanakan seperti: (1) mendesain identitas visual, yang meliputi logo, kemasan, signage, eksterior dan interior gedung, seragam, company profile, graphic standard manual, dan masih banyak lagi; (2) merancang komunikasi, seperti: iklan, laporan tahunan, public relation, dan sebagainya; dan (3) menetapkan perilaku, yang meliputi: nilai perusahaan, etos kerja, budaya perusahaan, dan lain-lain.

Untuk mempermudah pemahaman, brand dapat diperumpamakan sebagai manusia. Tiap manusia tentu memiliki karakter dan keunikan yang membedakannya dengan manusia yang lain, begitu juga dengan brand. Karakter manusia dapat dibaca dari banyak hal, seperti bagaimana cara berpenampilan, cara berbicara, dan masih banyak lagi. Namun, karakter manusia akan dibaca pertama kali melalui pakaian yang dikenakannya. Dalam hal ini, pakaian yang dikenakan manusia dapat diumpamakan sebagai identitas visual. Pada pandangan pertama masyarakat akan membaca karakter sebuah brand melalui identitas visual yang ditampilkannya.

Elemen identitas visual yang terpenting adalah logo. Logo selalu diterapkan dalam aplikasi identitas visual lainnya. Oleh karena itu penting untuk merencanakan logo yang dapat mencerminkan kepribadian dan jiwa sebuah brand.

Logo adalah elemen grafis yang berbentuk ideogram, simbol, emblem, ikon, tanda yang digunakan sebagai lambang sebuah brand. Logo adalah atribut utama brand yang terlihat secara fisik. 
Namun logo yang baik juga harus dapat menampilkan semua atribut nonfisik yang merupakan jiwa dari brand (visi misi, nilai, budaya). Logo dapat dibedakan menjadi beberapa tipe.

Logogram, adalah gambar yang mewakili sebuah makna. Atau secara lebih mudah dapat dikatakan logogram adalah logo yang dituangkan dalam bentuk gambar. Logogram yang baik dapat menjadi elemen visual yang kuat mudah diingat oleh masyarakat. Contoh logogram yang kuat dan diingat oleh masyarakat terdapat pada Gambar 2.

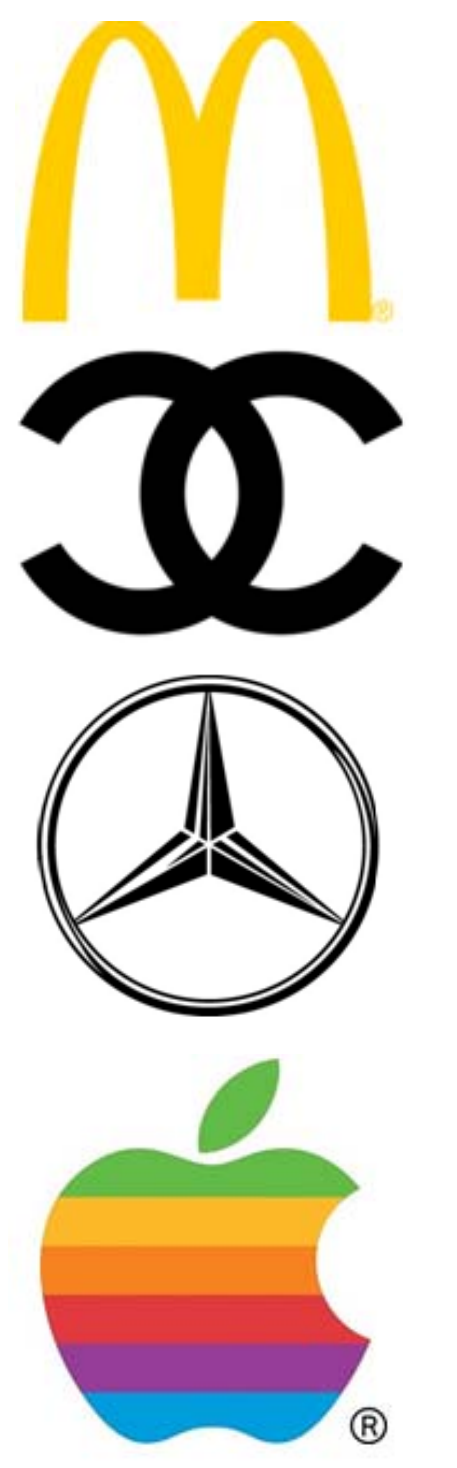

Tanpa perlu meletakkan nama brand, masyarakat sudah mengetahui bahwa logogram tersebut adalah logo Mc Donalds.

Walau tanpa keterangan nama brand, masyarakat, khususnya wanita, tentu mengetahui brand apakah ini. Chanel memang salah satu brand dengan logogram yang kuat.

Begitu juga dengan logogram di samping ini. Tanpa keterangan nama brand, masyarakat sudah mengetahui bahwa logogram ini mewakili brand Mercedes Benz.

Siapa yang tidak mengenal logogram yang mewakili brand Mac di samping ini?

Gambar 2 Contoh logogram

Logotype. Secara sederhana, logotype dapat didefinisikan sebagai logo yang merupakan hasil dari pengolahan font. Walau hanya memanfaatkan font, bukan berarti logo tidak memiliki keunikan. Pada umumnya pengunaan font jenis script menunjukkan formalitas, keindahan, bahkan terkadang keramahan. Font yang tebal menunjukkan kekuatan. Font yang italic menunjukkan pergerakan. Tiap font memiliki karakteristik yang dapat menyimbolkan karakter entitas yang diwakilinya. Beberapa brand terkenal yang menggunakan logotype sebagai logo: 


\section{ArrAsia}
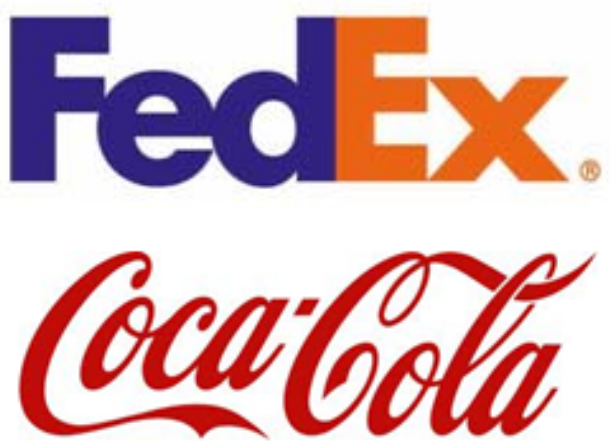

\section{N口KIA}

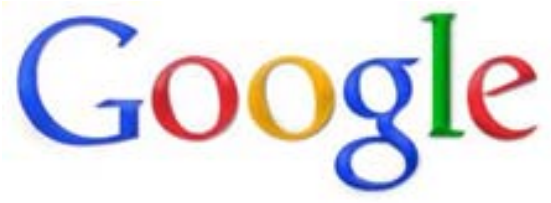

\section{SAMSUNG}

Gambar 3 Contoh logotype

Perpaduan antara logogram dan logotype. Pada umumnya, penerapan logogram dilengkapi dengan logotype sebagai yang diterangkan dan menerangkan. Namun ada beberapa logo yang memasukkan unsur logogram ke dalam logotype sehingga keduanya menjadi satu kesatuan. Beberapa contohnya antara lain:
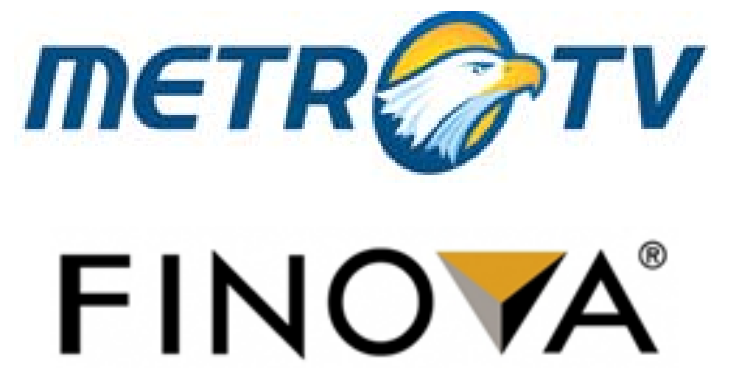

FINANCIAL INNOVATORS
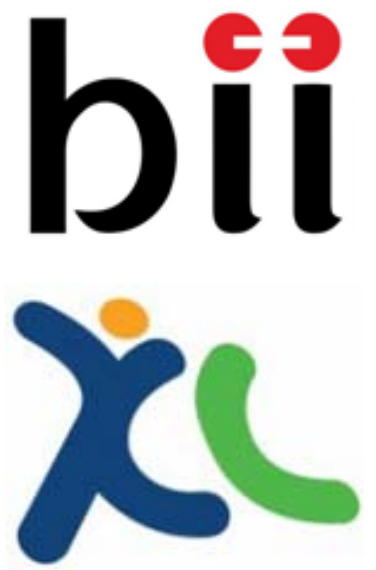

Gambar 4 Contoh logo perpaduan antara logogram dan logotype
Stilasi burung elang dalam lingkaran sekaligus menjadi huruf $\mathrm{O}$

Logogram pada logo Finova sekaligus terbaca sebagai huruf V.

Titik di atas huruf I sekaligus melambangkan kepada dua orang yang sedang berkomunikasi.

Huruf $\mathrm{X}$ juga sekaligus merupakan stilasi orang. 
Logo yang baik harus dapat menggambarkan kepribadian entitas yang diwakilinya. Logo tersebut harus memiliki keunikan yang dapat membedakan entitas yang diwakilinya dengan entitas lain. Namun yang perlu diperhatikan adalah logo harus tetap simpel dan fleksibel, baik secara bentuk, warna, maupun ukuran. Kenapa demikian? Logo akan diaplikasikan dalam berbagai identitas visual lain dalam beragam media. Dengan bentuk, warna, ukuran yang simpel dan fleksibel logo akan lebih aplikatif. Selain itu logo yang simpel juga lebih mudah diingat oleh masyarakat. Secara ringkas, beberapa kriteria standar yang harus dipenuhi sebuah logo dapat tergambar dalam Tabel 1.

Tabel 1 Kriteria standar sebuah logo

\begin{tabular}{cccc}
\hline & Unik & Simpel & Fleksibel \\
\hline Bentuk & $\mathrm{V}$ & $\mathrm{V}$ & $\mathrm{V}$ \\
Warna & & $\mathrm{V}$ & $\mathrm{V}$ \\
Ukuran & & & $\mathrm{V}$ \\
\hline
\end{tabular}

Sudah disebutkan secara berulang-ulang, logo harus dapat mencerminkan jiwa/kepribadian entitas yang diwakilinya. Bagaimana contoh penerapannya dalam logo-logo yang sudah ada?

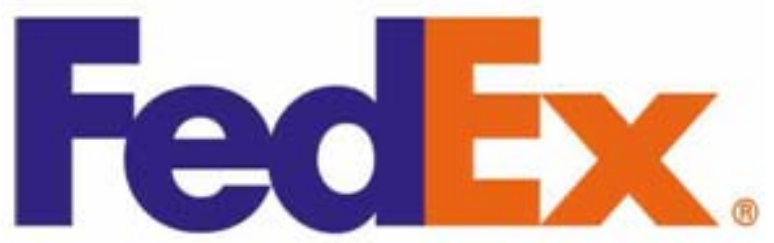

Gambar 5 Logo FedEx®

Logo FedEx sekilas tampak sederhana, namun ternyata logo ini memanfaatkan salah satu prinsip gestalt. Ruang negatif di antara E dan X menampilkan simbol tanda panah ke kanan. Kenapa simbol panah yang dipilih? Fed Ex adalah sebuah perusahaan jasa pengiriman barang. Sebagai layanan jasa pengiriman, janji yang ditawarkan Fex Ex kepada pelanggannya adalah kecepatan. Simbol panah dapat mewakili makna kecepatan itu. Selain itu tanda panah tersebut juga dapat diartikan sebagai lambang dari perusahaan yang selalu maju, memiliki visi ke depan dan memandang masa depan.

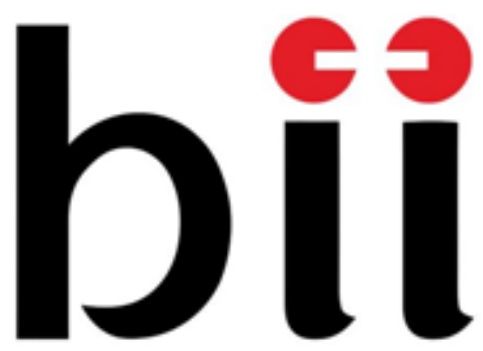

Gambar 6 Logo BII

Jika menelaah logo Bank BII, kedua huruf “i” menyimbolkan stilasi dua orang manusia. Dengan modifikasi yang dilakukan pada titik di atas kedua huruf i, kedua manusia itu tampak tengah bercakap. Dengan simbol tersebut, bank BII menjanjikan lebih dari sekedar keamanan, melainkan hubungan interpersonal yang otomatis juga melambangkan kepercayaan. 

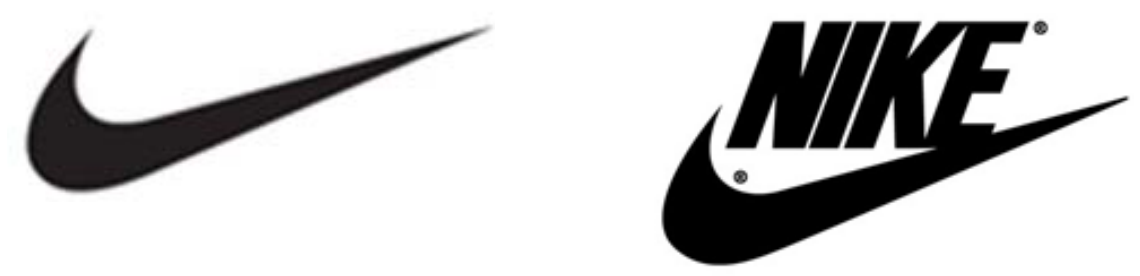

Gambar 7 Logo NIKE

Siapa yang tidak mengenal logogram ini? Tanpa perlu menempatkan nama brand, hampir semua orang sudah mengenali nama brand yang diwakilinya, yaitu Nike. Logogram ini dinamakan "swoosh." Lalu apa yang ingin disampaikan oleh logogram ini? Kepribadian apakah yang coba diwakilinya? Nike adalah brand sepatu olahraga yang memosisikan diri sebagai sepatu untuk pelari. Nama Nike sendiri diambil dari dewi kemenangan Yunani. Logogram ini merupakan stilasi dari sayap sang dewi kemenangan. Sehingga, secara implisit logogram ini menampilkan makna berlari dengan bantuan sayap dewi kemenangan dan meneriakkan kata, "menang!” Selain itu logogram ini juga memiliki makna ganda karena bentuknya yang merupai tanda centang, atau tanda positif, atau tanda keberhasilan.

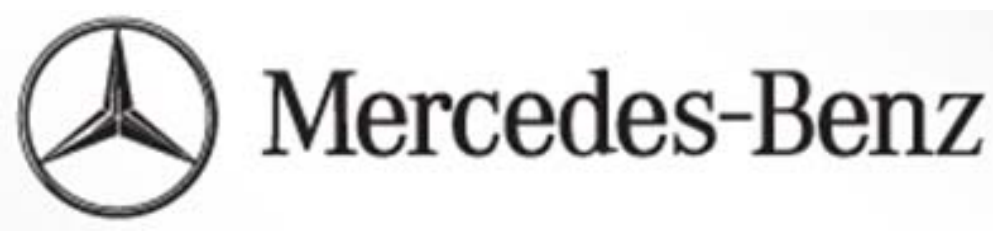

Gambar 8 Logo Mercedes-Benz

Logogram Mercedes-Benz menggambarkan semacam bintang yang memiliki tiga sudut. Bintang tiga sudut ini melambangkan bahwa Mercedes-Benz mendominasi baik di daratan, lautan, maupun udara.

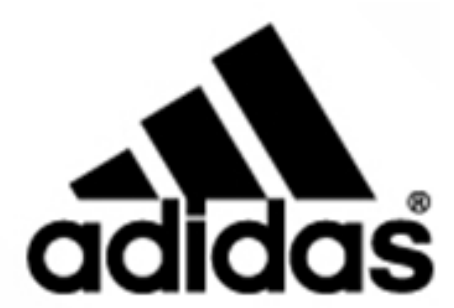

Gambar 9 Logo Adidas

Logogram Adidas berbentuk tiga garis yang menjulang ke atas. Hal ini melambangkan gunung, yang dapat diartikan sebagai tantangan yang ada di depan mata dan tujuan yang dicapai. Melalui logogram ini, Adidas menunjukkan jiwanya sebagai sepatu untuk orang-orang yang menyukai tantangan, dan berambisi menggapai tujuannya. 


\section{amazon.com}

Gambar 10 Logo Amazon.Com

Di bawah logotype amazon.com tampak panah yang mengarahkan dari huruf a ke z. Hal ini melambangkan bahwa amazon.com menjual semua jenis barang mulai dari a sampai z. Lengkungan panah tersebut juga membentuk senyuman.

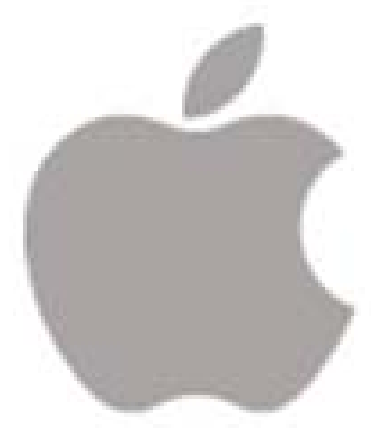

Gambar 11 Logo Apple

Logogram Mac yang berbentuk apel ini berasal dari cerita Adam dan Hawa. Dalam cerita tersebut apel merupakan lambang buah pengetahuan. Lalu kenapa ada gigitan di situ? Ini merupakan permainan dua kata yang sama cara membacanya yaitu Bite dan Byte. Pada jaman dahulu slogan Mac adalah Byte into an Apple.

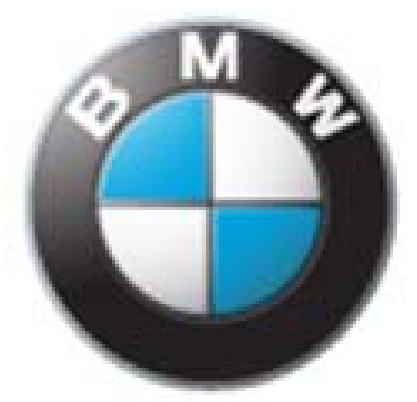

Gambar 12 Logo BMW

Logogram BMW berbentuk semacam medalion yang mewakili baling-baling pesawat yang berputar. Warna biru yang digunakan melambangkan langit. Kenapa BWM malah menggunakan simbol yang menggambarkan pesawat dan langit? Hal ini berkaitan dengan sejarah, di mana pada masa lalu BMW menciptakan mesin untuk pesawat militer Jerman pada perang dunia ke-2. Warna yang digunakan oleh logogram ini juga merupakan warna nasional Bavaria, yang sekarang merupakan bagian dari negara Jerman. 


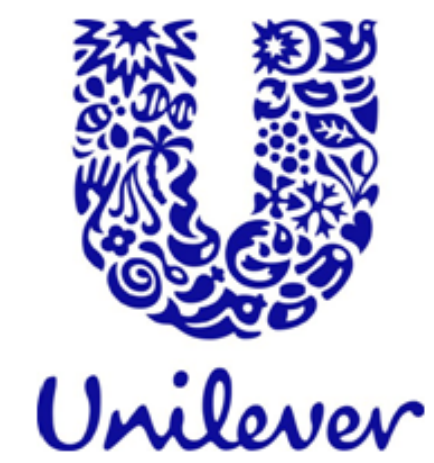

Gambar 13 Logo Unilever

Unilever adalah perusahaan multinasional yang mengelola multiproduk. Keberagaman inilah yang diangkat ke dalam logo Unilever. Logo unilever tersusun atas stilasi-stilasi yang melambangkan brand, keluarga besar unilever, dan nilai yang dianut. 'Our new identity is an expression of vitality which it at the heart of everything we do - our brands, our people, and our values.'
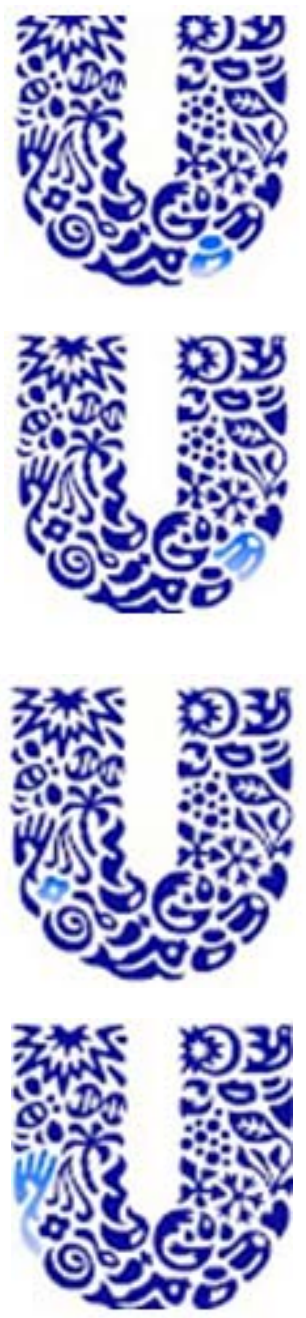

Stilasi container:

melambangkan kemasan -botol cream yang diasosiasikan dengan produk perawatan tubuh.

Stilasi baju:

melambangkan kesegaran pakaian dan penampilan.

Stilasi bunga:

Melambangkan aroma harum.

Stilasi tangan:

melambangkan sensitivitas, dan perawatan. Simbol ini melambangkan kulit dan sentuhan. 

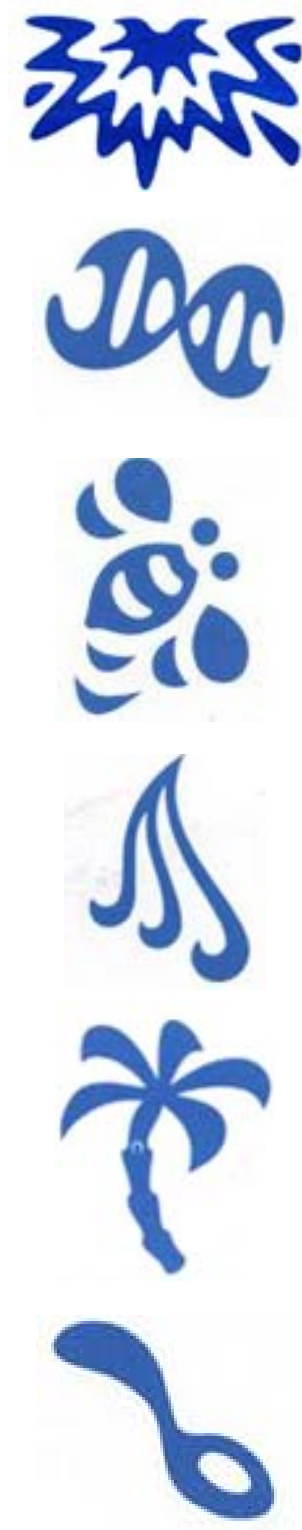

Stilasi sendok: simbol dari nutrisi, masak-memasak, dan rasa yang enak.

\section{Stilasi rambut:}

lambang kecantikan. Pada logo, stilasi rambut diletakkan di dekat tangan untuk menunjukkan kelembutan, dan di dekat bunga untuk menunjukkan keharuman dan kebersihan.

Stilasi pohon kelapa: sumber daya alam yang keseluruhan bagiannya dapat dimanfaatkan. Simbol ini juga melambangkan surga.

Gambar 14 Stilasi Logo Unilever

Mengingat pentingnya peranan logo dalam branding, seharusnya sebuah logo didesain dengan penuh perancangan. Sayangnya, berdasarkan penelitian, banyak logo, terutama logo entitas kecilmenengah yang didesain tanpa melalui proses perancangan yang matang. Contoh praktek pelaksanaannya antara lain:

Kontes desain logo. Hari demi hari kontes desain logo makin marak. Bahkan banyak bermunculan situs yang menjadi wadah kontes semacam itu. Sekilas, kontes-kontes seperti ini tampak sangat menguntungkan bagi entitas penyelenggara. Sang entitas mendapat banyak alternatif logo dari banyak desainer, memiliki kebebasan memilih, dan membayar dengan harga yang relatif murah. Namun jika ditelaah lebih lanjut, kelemahan kontes semacam ini adalah: (1) desainer peserta tidak diwajibkan melakukan riset. Akibatnya, logo-logo yang dihasilkan hanya indah secara visual namun sering kali tidak mencerminkan kepribadian perusahaan; (2) karena tidak ada jaminan menang dan mendapat honor, sering kali desainer peserta mengambil jalan pintas. Demi bekerja secara cepat, 
peserta memodifikasi logo/visual yan sudah ada, atau bahkan menyadurnya. Logo tersebut akan menjadi generik; (3) desainer hanya bekerja berdasar brief singkat, tanpa ada timbal balik secara terusmenerus dari klien. Sementara dalam pengembangan desain logo, komunikasi timbal balik ini sangat penting. Klien adalah orang yang paling tahu mengenai kepribadian perusahaan mereka.

Jasa pembuatan logo murah meriah dalam 24 jam. Baik di situs-situs maupun di pinggir jalan, banyak layanan pembuatan logo dengan harga yang luar biasa murah dan dalam waktu yang sangat singkat. Dengan waktu sesingkat itu, dapat dibayangkan seberapa instan proses pendesainan logo, dan seberapa instan hasilnya. Pada akhirnya, logo tidak bisa menjadi pintu gerbang yang mencerminkan kepribadian brand yang bersangkutan. Logo juga tidak memiliki keunikan yang akan membuatnya stand out dan diingat dibanding logo perusahaan lain.

Penggunaan template gratis, stock imagery. Di situs-situs yang bertebaran di internet banyak ditemukan template atau stock imagery yang dapat digunakan sebagai logo. Penggunaan template atau stock imagery semacam ini sangat merugikan brand. Template atau stock imagery semacam ini dapat diunduh oleh ribuan bahkan jutaan orang. Logo akan menjadi generik, bahkan tidak menutup kemungkin sama dengan logo brand lain. Desain logo yang orisinal akan membangun kepribadian dan menunjukkan jiwa sebuah brand.

Lalu mengapa layanan desain logo murah dan tanpa melalui perencanaan matang yang nyatanya menghasilkan logo generik dan dangkal masih sangat marak? Berdasarkan pengamatan, beberapa faktor yang menyebabkan hal tersebut. Dari segi pengusaha, yaitu: (1) masyarakat, khususnya pemilik perusahaan, belum menyadari betapa pentingnya membangun sebuah brand; (2) masyarakat, khususnya pemilik perusahaan, kurang menyadari bahwa logo adalah pintu gerbang yang mencerminkan kepribadian brand. Logo harus dirancang untuk kepentingan jangka panjang, bukan hanya pemanis yang dilihat secara fisik; dan (3) masyarakat, khususnya pemilik perusahaan, tidak menyadari bahwa sebuah brand yang baik dapat memiliki aspek finansial yang sangat tinggi. Oleh sebab itu, mereka tidak rela mengeluarkan dana yang besar untuk merancang sebuah logo.

Dari sisi desainer, yaitu: (1) desainer sendiri kurang memahami pentingnya logo dalam membangun sebuah brand. Mereka hanya memandang logo dari sisi fisik sebagai pemanis; (2) kemajuan teknologi dan kemudahan yang ditawarkan komputer membentuk pola pikir bahwa membuat logo itu mudah. Karena kemudahan tersebut, mereka rela dibayar murah asal mendapat uang secara cepat. Hal ini akan membentuk sebuah lingkaran setan, karena banyak desainer yang berlombalomba menurunkan harga demi memenangkan proyek sehingga di masa depan desain logo akan semakin murah. Para desainer semacam ini tidak menghargai profesi mereka sendiri.

Berdasarkan pemaparan di atas, ternyata kurangnya kesadaran akan pentingnya peranan logo dalam membangun brand bukan hanya terjadi di kalangan pengusaha sebagai klien, melainkan juga di kalangan para desainer. Beberapa hal yang bisa dilakukan untuk memperbaiki situasi ini antara lain: (1) diadakannya seminar-seminar baik untuk pengusaha maupun desainer mengenai pentingnya membangun brand, dan pentingnya peranan logo dalam membentuk sebuah brand; dan (2) membangkitkan kesadaran para desainer untuk lebih menghargai profesi mereka sendiri. Hal ini bisa dilakukan melalui banyak kegiatan seperti seminar, workshop, maupun kampanye.

Pengusaha sebagai pemilik brand dan desainer seharusnya membentuk suatu simbiosis mutualisme. Jika tidak ada kerja sama dan kesadaran dari kedua belah pihak, perbaikan tidak akan terjadi. Kedua belah pihak ini harus menanamkan kesadaran bahwa walau tidak kasat mata, brand adalah aset yang tak bernilai harganya. Oleh karena itu, branding harus dilakukan dengan perencanaan matang, termasuk logo yang menjadi cerminan jiwa/kepribadian entitas. Harus diingat bahwa brand yang dibangun dengan baik akan menimbulkan loyalitas pelanggan. 


\section{SIMPULAN}

Brand adalah aset tak berwujud yang paling bernilai dari sebuah entitas. Oleh karena itu, branding harus digarap dengan serius, termasuk desain logo sebagai pintu masuk yang mencerminkan brand. Logo harus mencerminkan jiwa/kepribadian brand yang diwakilinya. Logo juga harus memiliki keunikan yang dapat membedakan suatu entitas dengan entitas lainnya. Maraknya praktik layanan logo cepat saji dan murah tidak bisa dianggap enteng. Praktik tersebut menghasilkan logo instan yang generik. Hal ini akan menjadi lingkaran setan yang makin lama makin menjatuhkan nilai logo, dan menghancurkan brand. Untuk memperbaiki kondisi tersebut, diperlukan kerja sama antara pemilik brand dan desainer. Kesadaran dari kedua belah pihak tersebut harus digugah demi kepentingan bersama.

\section{DAFTAR PUSTAKA}

Rustan, S. (2009). Mendesain logo. Jakarta: Gramedia Pustaka Utama.

Wheeler, A. (2009). Designing brand identity. New Jersey: John Wiley \& Sons. 